\title{
Faktor-Faktor yang Memengaruhi Kejadian Defisiensi dan Insufisiensi Vitamin D pada Pasien Anak dengan Penyakit Ginjal Kronis
}

\author{
Anies Mediressia, Eka Intan Fitriana, Achirul Bakri, Hertanti Indah Lestari \\ Departemen Ilmu Kesehatan Anak Fakultas Kedokteran Universitas Sriwjaya/RSUP dr. Mohammad Hoesin, Palembang
}

\begin{abstract}
Latar belakang. Peranan vitamin D penting untuk optimalisasi tata laksana penyakit ginjal kronis (PGK). Defisiensi vitamin D sering terjadi pada pasien PGK. Beberapa cara untuk mencegahnya adalah dengan mengendalikan faktor-faktor yang menyebabkan defisiensi vitamin D dan memberikan suplementasi vitamin D pada pasien PGK.

Tujuan. Untuk mengetahui faktor-faktor yang memengaruhi kejadian defisiensi dan insufisiensi 25(OH)D.

Metode. Studi potong lintang dengan analisis regresi logistik terhadap pasien PGK derajat 1-5 berusia 1-17 tahun di RS Muhammad Hoesin Palembang pada Agustus 2019 hingga April 2020. Kadar 25(OH)D diperiksa menggunakan metode enzyme immunoassay dan dikategorikan menjadi defisiensi, insufisiensi dan normal sesuai rekomendasi American Academy of Pediatric.

Hasil. Didapatkan 70 pasien PGK dalam penelitian ini. Defisiensi 25(OH)D terjadi pada 64,3\% subjek, insufisiensi pada 7,1\% dan normal pada 28,6\% subjek. Sebagian besar subjek dengan PGK derajat 1 dan 5 . Analisis multivariat menunjukkan usia $<14$ tahun, lama diagnosis $\geq 2$ tahun dan hipoalbuminemia memberikan risiko lebih tinggi pada pasien PGK untuk mengalami defisiensi 25(OH)D dengan OR berturutturut 5,$6 ; 5,1 ; 21,2(\mathrm{p}<0,05)$.

Kesimpulan. Angka kejadian defisiensi vitamin D anak PGK 64,3\%. Faktor risiko bermakna terhadap kejadian defisiensi vitamin D, yaitu hipoalbuminemia, usia $<14$ tahun dan lama terdiagnosis $\geq 2$ tahun. Sari Pediatri 2021;23(1):36-42
\end{abstract}

Kata kunci: PGK, penyakit ginjal kronis, vitamin D, 25(OH)D, 25-hydroxyvitamin D, faktor risiko, anak

\section{Risk Factor of Vitamin D Deficiency and Insufficiency in Children with Chronic Kidney Disease}

Anies Mediressia, Eka Intan Fitriana, Achirul Bakri, Hertanti Indah Lestari

Background. Vitamin D has an important role in optimizing management of chronic kidney disease (CKD). Vitamin D deficiency is common among CKD patients, which can be prevented by restraining the contributing factors and giving vitamin $\mathrm{D}$ supplements CKD patients. Objective. To determine the contributing factors of vitamin $\mathrm{D}$ deficiency in children with $\mathrm{CKD}$

Methods. This cross-sectional study with logistic regression approach included stage 1-5 CKD patients aged 1-17 years old who admitted to Mohammad Hoesin General Hospital from August 2019 to April 2020 consecutively. The level of 25(OH)D was analyzed by enzyme immunoassay method and categorized into deficiency, insufficiency and normal based on American Academy of Pediatric.

Results. There were 70 subjects included in this study. Vitamin D deficiency was found in $64,3 \%$ of subjects, insufficiency in $7,1 \%$ and normal in 28,6\%. Most subjects were stage 1 and 5 CKD patients. Multivariate analysis showed that CKD patients aged $<14$ years old, diagnosed $\geq 2$ years and had hypoalbuminemia were at greater risk for $25(\mathrm{OH}) \mathrm{D}$ deficiency with OR 5,6; 5,1; $21,2(\mathrm{p}<0.05)$ respectively. Conclusion. We found a high prevalence of vitamin D deficiency in pediatric CKD patients in this study. Younger age ( $<14$ years old), hypoalbuminemia and longer diagnosis period ( $\geq 2$ years) are significant factors affecting vitamin D deficiency. Sari Pediatri 2021;23(1):36-42

Keywords: CKD, chronic kidney disease, vitamin D, 25(OH)D, 25-hydroxyvitamin D, risk factor, children

Alamat korespondensi: Hertanti Indah Lestari. Departemen Ilmu Kesehatan Anak Fakultas Kedokteran Universitas Sriwijaya/ RSUP Dr. Mohammad Hoesin Palembang. Jalan Jenderal Sudirman KM 3,5 Palembang 30126, Indonesia. Email: hertantilestari@unsri.ac.id 
Anies Mediressia dkk: Faktor-faktor yang memengaruhi kejadian defisiensi dan insufisiensi vitamin D pada anak dengan PGK

$\mathrm{P}$ enyakit ginjal kronik (PGK) merupakan suatu penyakit yang ditandai dengan kehilangan fungsi ginjal progresif yang dapat berakhir pada Penyakit Ginjal Tahap Akhir (PGTA). Ginjal memiliki banyak fungsi penting seperti filtrasi, reabsorpsi, regulasi osmotik, sekresi hormon dan menjaga keseimbangan elektrolit dan asam - basa. Ginjal mengatur pengeluaran hormon dan enzim seperti adrenalin, eritropoietin, 1-a hidroksilase, hormon diuretik dan antidiuretik. ${ }^{1}$ Gangguan akibat PGK, salah satunya adalah terganggunya proses hidroksilasi kedua vitamin $\mathrm{D}$ dari $25(\mathrm{OH}) \mathrm{D}$ menjadi $1,25(\mathrm{OH})$ D. Gangguan PGK lainnya adalah mengakibatkan proteinuria dan hilangnya protein pengikat vitamin D yang mengakibatkan penurunan kadar vitamin D. ${ }^{2}$

Vitamin D memiliki peranan penting dalam proses metabolisme tubuh manusia, seperti mengatur homeostasis kalsium dan fosfat dalam mineralisasi tulang dan fungsi neuromuskular. Vitamin D pada pasien PGK terbukti menurunkan morbiditas dan mortalitas serta komplikasi dari PGK. ${ }^{3}$

Kejadian defisiensi vitamin D cukup sering terjadi pada populasi anak normal, sekitar 14-25\% anak memiliki kadar $25(\mathrm{OH}) \mathrm{D} \leq 20 \mathrm{ng} / \mathrm{ml}$. Kejadian defisiensi dan insufisiensi vitamin $\mathrm{D}$ pada anak dengan PGK lebih tinggi dibandingkan pada populasi normal. ${ }^{2}$ Defisiensi vitamin D pada pasien PGK dipengaruhi oleh beberapa faktor spesifik dan non spesifik. Faktor non spesifik meliputi ras berkulit gelap, usia yang lebih besar, jenis kelamin perempuan, indeks massa tubuh (IMT) tinggi, paparan sinar matahari rendah, lamanya menonton tv/komputer, asupan susu inadekuat, asupan vitamin D inadekuat. Faktor risiko spesifik pada pasien PGK berupa terganggunya fotosintesis kutaneus dari kalsiferol karena uremia, sekresi paratiroid hormon, kehilangan protein pengikat vitamin D (Vitamin D binding protein/DBP) dari urin, kehilangan albumin, berkurangnya asupan olahan susu karena restriksi fosfat. ${ }^{1,2,4}$ Pada penelitian sebelumnya didapatkan bahwa PGK derajat 3-5, glomerulosklerosis fokal segmental dan kadar albumin rendah merupakan faktor yang secara signifikan berkaitan dengan kadar vitamin D yang rendah. ${ }^{2}$ Penelitian ini bertujuan untuk mengidentifikasi kadar vitamin $D$, prevalensi dan faktor-faktor yang memengaruhi defisiensi dan insufisiensi vitamin D pada anak-anak dengan PGK di RSMH.

\section{Metode}

Penelitian ini dilakukan di poliklinik khusus nefrologi anak dan rawat inap KSM Anak RS Muhammad Hoesin Palembang pada Agustus 2019 - April 2020. Penelitian ini merupakan studi analitik observasional dengan menggunakan rancangan potong lintang. Semua pasien PGK berusia 1-17 tahun yang memenuhi kriteria inklusi diambil secara konsekutif. Kriteria eksklusi adalah pasien dengan kelainan endokrin, riwayat terapi bifosfonat, klinis gagal hati, kelainan digestif terkait malabsorsi, riwayat paratiroidektomi maupun riwayat transplantasi ginjal. Data demografik seperti usia, jenis kelamin, lama terdiagnosis dan faktor terkait seperti penyakit dasar, kadar $25(\mathrm{OH}) \mathrm{D}$, derajat PGK, lama paparan sinar matahari, penggunaan sunscreen, suplementasi vitamin $\mathrm{D}$, penggunaan steroid, kadar albumin, ureum dan protein urin didapatkan dari anamnesis, pemeriksaan fisik, pemeriksaan laboratorium dan rekam medik pasien. Sampel 25(OH)D diberikan label dan dianalisis di laboratorium RS Muhammad Hoesin Palembang (RSMH) menggunakan metode enzyme immunoassays (EIA). Status 25(OH)D dikategorikan berdasarkan kategori American Academy of Pediatrics (AAP,2008) yaitu defisiensi $(\leq 15 \mathrm{ng} / \mathrm{ml})$, insufisiensi $(16-20 \mathrm{ng} / \mathrm{ml})$ and normal $(\geq 21 \mathrm{ng} / \mathrm{ml}) .{ }^{5}$ Fungsi ginjal dinilai dengan menggunakan laju filtrasi glomerulus (LFG) berdasarkan rumus Schwartz. Derajat PGK dikategorikan menjadi derajat 1 hingga 5 berdasarkan rekomendasi kidney disease outcome quality initiative (KDOQI, 2012). ${ }^{6}$ Lama paparan sinar matahari per hari saat jam 09.00 hingga 14.00 , setidaknya $3 x$ /minggu dikategorikan menjadi pendek ( $<30$ menit), sedang (30-60 menit) dan panjang (>60 menit). Suplementasi vitamin $\mathrm{D}$ termasuk semua bentuk vitamin D baik D2, D3 maupun vitamin D aktif dosis berapapun setiap hari atau selang sehari selama 30 hari terakhir. Penggunaan steroid oral dosis berapapun selama $>14$ hari dalam 30 hari terakhir dianggap sebagai faktor risiko dalam penelitian ini. Pasien dianggap hipoalbuminemia bila kadar albumin $<2,5 \mathrm{~g} / \mathrm{dl}$, uremia bila kadar ureum $>60$ $\mathrm{mg} / \mathrm{dl}$. Proteinuria ditandai dengan ekskresi protein dalam 1 waktu dengan nilai pada pemeriksaan dipstick $\geq 2+$.

Analisis statistik dilakukan menggunakan perangkat lunak SPSS untuk windows versi 24.0. Analisis menggunakan regresi logistik untuk mengetahui faktor-faktor yang berpengaruh terhadap kejadian 
defisiensi-insufisiensi 25(OH)D. Tingkat kemaknaan dinyatakan signifikan bila nilai p kurang dari 0,05. Penelitian ini telah disetujui oleh komite etik Fakultas Kedokteran Univesitas Sriwijaya, Palembang. Informed consent didapatkan dari seluruh orang tua pasien yang diikutkan dalam penelitian ini.

\section{Hasil}

Terdapat 70 subjek yang memenuhi kriteria inklusi penelitian, karakterisitik subjek tertera pada Tabel 1 . Lebih banyak pasien PGK berjenis kelamin laki-laki $(64,3 \%)$ dibanding perempuan dengan rasio 2:1. Mayoritas pasien berusia 7-13 $(67,1 \%)$ tahun. Etiologi PGK terbanyak adalah sindrom nefrotik resisten steroid (SNRS) pada $22(31,4 \%)$ orang, disusul oleh sindrom nefrotik sensitif steroid (SNSS) yang ditemukan pada $19(27,15 \%)$ dan CAKUT pada $10(14,3 \%)$ orang. Lama terdiagnosis terbanyak pada kelompok $\geq 2$ tahun (65,7\%).

Pada penelitian banyak ditemukan pasien dengan PGK derajat 1, yakni $39(55,7 \%)$ dan derajat 5 , yaitu $21(30 \%)$. Dari 21 orang pasien dengan PGK derajat 5,12 orang di antaranya menjalani peritoneal dialisis dan 9 lainnya menjalani hemodialisis. Mayoritas subjek mengalami defisiensi $25(\mathrm{OH}) \mathrm{D}$, yaitu $45(64,3 \%)$, insufisiensi $5(7,1 \%)$, dan kadar vitamin D normal $20(28,6 \%)$. Pasien dengan PGK terbanyak memiliki paparan sinar matahari durasi sedang $(54,3 \%)$. Hanya 19 orang $(27,1 \%)$ yang terdiri dari pasien PGK derajat 5 dan pasien dengan SLE yang mendapat suplementasi vitamin $\mathrm{D}$, semuanya mendapatkan suplemen berupa kalsitriol 0,05-0,1 mcg yang diminum setiap hari.

Hasil analisis bivariat dari berbagai faktor yang memengaruhi terjadinya defisiensi dan insufisiensi $25(\mathrm{OH}) \mathrm{D}$ tertera pada Tabel 2. Hipoalbuminemia merupakan faktor yang berhubungan secara signifikan dengan kejadian defisiensi-insufisiensi 25(OH)D.

Analisis mutivariat dilakukan untuk menilai faktor yang memengaruhi defisiensi dan insufisiensi $25(\mathrm{OH}) \mathrm{D}$ secara bersamaan. Hasil analisis pada Tabel 3 menunjukkan bahwa usia 1-13 tahun, lama terdiagnosis $\geq 2$ tahun dan hipoalbuminemia merupakan faktor yang dapat secara independen memengaruhi terjadinya defisiensi 25(OH)D. Pasien PGK dengan usia 1-13 tahun memiliki risiko 5,6 kali untuk terjadi defisiensi maupun insufisiensi 25(OH)D dibandingkan pasien yang berusia 14-17 tahun. Durasi sakit $\geq 2$ tahun memiliki risiko 5,1 kali untuk terjadi defisiensi maupun insufisiensi $25(\mathrm{OH}) \mathrm{D}$ dibandingkan pasien dengan durasi sakit $<2$ tahun. Pasien hipoalbuminemia memiliki risiko 21,9 kali untuk terjadi defisiensi maupun insufisiensi $25(\mathrm{OH}) \mathrm{D}$ dibandingkan pasien yang tidak mengalami hipoalbuminemia.

\section{Pembahasan}

Usia pasien berkisar antara 4 hingga 17 tahun dengan median 11 tahun dan rerata $11,23 \pm 3,28$ tahun. Hasil temuan ini hampir sama dengan penelitian $\mathrm{Kumar}^{1}$ dengan median usia 10,7 tahun $(7,3-14,2)$ tahun. Rerata usia sedikit lebih rendah dari penelitian Kalkwarf ${ }^{2}$ bahwa rerata usia pasien anak dengan PGK adalah 13-14 tahun. Kisaran usia ini sesuai dengan etiologi terbanyak SN yang paling banyak terjadi pada anak usia 12-18 tahun, sedangkan CAKUT banyak terjadi pada anak usia $<2$ tahun. $^{7}$

Setelah dilakukan pengukuran kadar vitamin D pada anak, ditemukan 64,3\% anak mengalami defisiensi vitamin D. Penemuan ini menunjukkan tingkat defisiensi yang lebih tinggi bila dibandingkan dengan penelitian Kumar, ${ }^{1}$ Lee, ${ }^{5}$ Stein, ${ }^{8}$ dan Seeherunvong 9 yang menunjukkan kejadian defisiensi $25(\mathrm{OH}) \mathrm{D}$ berkisar antara $16-54,9 \%$. Hal ini mungkin dapat disebabkan oleh gaya berpakaian di Indonesia yang cenderung lebih tertutup. Angka defisiensi ini cukup tinggi meskipun Indonesia adalah negara tropis dan sebagian besar subjek tidak menggunakan sunscreen. Hal tersebut menunjukkan bahwa banyak faktor lain yang memengaruhi kadar $25(\mathrm{OH}) \mathrm{D}$ selain paparan sinar matahari, mungkin dapat berupa asupan makanan mengandung vitamin D maupun kadar PTH yang tidak diteliti dalam studi ini.

Didapatkan 55,7\% pasien dengan PGK derajat 1 dan sekitar sepertiga (30\%) dengan PGK derajat 5. Hasil ini tidak sesuai dengan penelitian Ardissino dkk ${ }^{10}$ yang melaporkan kejadian PGK terbanyak, yaitu derajat $3(67 \%)$, diikuti derajat $4(19 \%)$, dan derajat $5(14 \%)$. Begitu juga Mong Hiep $\mathrm{dkk}^{11}$ yang melaporkan kasus PGK terbanyak, yaitu derajat 2-3 (82\%) dan PGK 4-5 (18\%). Data epidemiologi mengenai angka kejadian PGK derajat 1 masih terbatas karena PGK derajat 1 seringkali asimptomatik ataupun tidak terdiagnosis dan tidak dilaporkan. 
Tabel 1. Karakterisitik subjek (N=70)

\begin{tabular}{|c|c|c|}
\hline & $\mathrm{n}(\%)$ & Median (rentang) atau Mean \pm SD \\
\hline \multicolumn{3}{|l|}{ Jenis kelamin (\%) } \\
\hline Laki-laki & $45(64,3)$ & \\
\hline Perempuan & $25(35,7)$ & \\
\hline Usia (\%, tahun) & & $11,23 \pm 3,28$ \\
\hline $1-6$ & $4(5,7)$ & \\
\hline 7-13 & $47(67,1)$ & \\
\hline $14-17$ & $19(27,1)$ & \\
\hline \multicolumn{3}{|l|}{ Etiologi (\%) } \\
\hline SNSS & $19(27,1)$ & \\
\hline SNRS & $22(31,4)$ & \\
\hline GNK & $9(12,9)$ & \\
\hline CAKUT & $10(14,3)$ & \\
\hline Neurogenic Bladder & $3(4,3)$ & \\
\hline ATR & $4(5,7)$ & \\
\hline Lain-lain & $3(4,3)$ & \\
\hline Lama diagnosis (\%, tahun) & & $3(1-12)$ \\
\hline$<2$ tahun & $24(34,3)$ & \\
\hline$\geq 2$ tahun & $46(65,7)$ & \\
\hline Kadar 25 (OH)D (\%, ng/mL) & & $14,30 \pm 8,82$ \\
\hline Defisiensi & $45(64,3)$ & \\
\hline Insufisiensi & $5(7,1)$ & \\
\hline Normal & $20(28,6)$ & \\
\hline LFG $\left(\mathrm{mL} / \mathrm{min} / 1,73 \mathrm{~m}^{2}\right)$ & & $104(3,5-384,7)$ \\
\hline \multicolumn{3}{|l|}{ Derajat PGK (\%) } \\
\hline Derajat 1 & $39(55,7)$ & \\
\hline Derajat 2 & $3(4,3)$ & \\
\hline Derajat 3 & $4(5,7)$ & \\
\hline Derajat 4 & $3(4,3)$ & \\
\hline Derajat 5 & $21(30)$ & \\
\hline Lama paparan sinar matahari (\%, menit) & & $30(10-120)$ \\
\hline Pendek & $27(38,6)$ & \\
\hline Sedang & $38(54,3)$ & \\
\hline Panjang & $5(7,1)$ & \\
\hline \multicolumn{3}{|l|}{ Penggunaan sunscreen $S P F \geq 8$ (\%) } \\
\hline Ya & $3(4,3)$ & \\
\hline Tidak & $67(95,7)$ & \\
\hline \multicolumn{3}{|l|}{ Suplemen vitamin D (\%) } \\
\hline Ya & $19(27,1)$ & \\
\hline Tidak & $51(72,9)$ & \\
\hline \multicolumn{3}{|l|}{ Penggunaan steroid (\%) } \\
\hline Ya & $27(38,6)$ & \\
\hline Tidak & $43(61,4)$ & \\
\hline Albumin (g/dL) (\%) & & $3,03 \pm 1,07$ \\
\hline Hipoalbuminemia & $19(27,1)$ & \\
\hline Tidak hipoalbuminemia & $51(72,9)$ & \\
\hline \multicolumn{3}{|l|}{ Proteinuria $(\%)$} \\
\hline Ya & $29(41,4)$ & \\
\hline Tidak & $41(58,6)$ & \\
\hline Uremia $(\%, \mathrm{mg} / \mathrm{dL})$ & & $30(4,8-394)$ \\
\hline Ya & $25(35,7)$ & \\
\hline Tidak & $45(64,3)$ & \\
\hline
\end{tabular}


Tabel. 2 Faktor risiko defisiensi dan insufisiensi 25(OH)D pada PGK

\begin{tabular}{|c|c|c|c|c|}
\hline \multirow[b]{2}{*}{ Variabel } & \multicolumn{4}{|c|}{ Status $25(\mathrm{OH}) \mathrm{D}$} \\
\hline & $\begin{array}{l}\text { Defisiensi- } \\
\text { insufisiensi } \\
\mathrm{n}(\%)\end{array}$ & $\begin{array}{c}\text { Normal } \\
\mathrm{n}(\%)\end{array}$ & $\mathrm{P}$ & OR(IK95\%) \\
\hline \multicolumn{5}{|l|}{ Jenis kelamin } \\
\hline Laki-laki & $29(64,4)$ & $16(35,6)$ & $0,083^{\mathrm{a}}$ & $2,89(0,8-9,9)$ \\
\hline Perempuan & $21(84,0)$ & $4(16,0)$ & & \\
\hline \multicolumn{5}{|l|}{ Usia (tahun) } \\
\hline $14-17$ & $12(63,2)$ & $7(36,8)$ & $0,350^{a}$ & $0,58(0,2-1,8)$ \\
\hline $1-13$ & $38(74,5)$ & $13(25,5)$ & & \\
\hline \multicolumn{5}{|l|}{ Etiologi } \\
\hline Glomerular & $38(76,0)$ & $12(24,0)$ & $0,181^{\mathrm{a}}$ & $2,11(0,7-6,4)$ \\
\hline Non glomerular & $12(60,0)$ & $8(40,0)$ & & \\
\hline \multicolumn{5}{|l|}{ Derajat PGK } \\
\hline Derajat 3-5 & $19(67,9)$ & $9(32,1)$ & $0,589^{\mathrm{a}}$ & $0,75(0,3-2,1)$ \\
\hline Derajat 1-2 & $31(73,8)$ & $11(26,2)$ & & \\
\hline \multicolumn{5}{|l|}{ Lama diagnosis } \\
\hline$\geq 2$ tahun & $20(83,3)$ & $4(16,7)$ & $0111^{\mathrm{a}}$ & $266(07-91)$ \\
\hline$<2$ tahun & $30(65,2)$ & $16(34,8)$ & $0,111^{a}$ & $2,06(0, /-9,1)$ \\
\hline \multicolumn{5}{|c|}{ Lama paparan sinar matahari } \\
\hline$<60$ menit & $39(73,6)$ & $14(26,4)$ & $0,543^{\mathrm{b}}$ & $1,52(0,5-4,9)$ \\
\hline$\geq 60$ menit & $11(64,7)$ & $6(35,3)$ & & \\
\hline \multicolumn{5}{|c|}{ Penggunaan sunscreen $S P F \geq 8$} \\
\hline Tidak & $48(71,6)$ & $19(28,4)$ & $1,000^{\mathrm{b}}$ & $1,26(0,1-14,8)$ \\
\hline Ya & $2(66,7)$ & $1(33,3)$ & & \\
\hline \multicolumn{5}{|c|}{ Suplemen vitamin D } \\
\hline Tidak & $35(68,6)$ & $16(31,4)$ & $0,395^{\mathrm{b}}$ & $0,58(0,1-2,0)$ \\
\hline $\mathrm{Ya}$ & $15(78,9)$ & $4(21,1)$ & & \\
\hline \multicolumn{5}{|l|}{ Penggunaan steroid } \\
\hline Ya & $21(77,8)$ & $6(22,2)$ & $0,351^{\mathrm{a}}$ & $1,69(0,5-5,1)$ \\
\hline Tidak & $29(67,4)$ & $14(32,6)$ & & \\
\hline \multicolumn{5}{|l|}{ Hipoalbuminemia } \\
\hline Ya & $18(94,7)$ & $1(5,3)$ & $0,008^{\mathrm{a}}$ & $10,6(1,3-86,5)$ \\
\hline Tidak & $32(6,7)$ & $19(37,3)$ & & \\
\hline \multicolumn{5}{|l|}{ Proteinuria } \\
\hline $\mathrm{Ya}$ & $20(69,0)$ & $9(31,0)$ & $0,701^{\mathrm{a}}$ & $0,81(0,2-2,3)$ \\
\hline Tidak & $30(73,2)$ & $11(26,8)$ & & \\
\hline \multicolumn{5}{|l|}{ Uremia } \\
\hline Ya & $20(80,0)$ & $5(20,0)$ & $0,237^{\mathrm{a}}$ & $2,0(0,6-6,3)$ \\
\hline Tidak & $30(66,7)$ & $15(33,3)$ & & \\
\hline
\end{tabular}

Tabel 3. Analisis multivariat faktor yang memengaruhi kejadian defisiensi dan Insufisiensi 25(OH)D

\begin{tabular}{lccc}
\hline Faktor & $\mathrm{B}$ & $\mathrm{P}$ & OR (IK 95\% ) \\
\hline Usia 1-13 tahun & 1,734 & 0,035 & $5.662(1,133-28,294)$ \\
Lama sakit $\geq 2$ tahun & 1,633 & 0,041 & $5.122(1,069-24,547)$ \\
Hipoalbumin & 3,054 & 0,013 & $21.192(1,928-232,935)$ \\
\hline
\end{tabular}


Anies Mediressia dkk: Faktor-faktor yang memengaruhi kejadian defisiensi dan insufisiensi vitamin D pada anak dengan PGK

Sebanyak 27 anak memiliki paparan sinar matahari dengan durasi pendek $(38,6 \%)$ dan 38 anak dengan paparan sedang $(54,3 \%)$. Rata-rata waktu yang dihabiskan di luar adalah 34,93 $\pm 23,16$ menit (rentang 10-120 menit), lebih pendek dibandingkan dengan rerata waktu yang dilaporkan oleh Stein, ${ }^{8}$ yaitu 1-2 jam per hari. Temuan paparan terbanyak durasi sedang ini seiring dengan jumlah pasien PGK derajat 1 yang lebih banyak pada penelitian ini. Pasien dengan PGK derajat 1 masih dapat melakukan aktifitas yang lebih banyak dan bisa menghabiskan waktu di luar pada pagi hari baik saat di rumah maupun pada pasien yang masih bersekolah yang bermain di luar kelas.

Hanya sebagian kecil pasien yang mendapat suplementasi vitamin D, yakni $19(27,1 \%)$, sedangkan yang tidak mendapat suplementasi vitamin $\mathrm{D}$ adalah $51(72,9 \%)$. Hasil ini lebih rendah daripada laporan Stein ${ }^{8}$ terhadap 99 pasien anak dengan PGK. Stein ${ }^{8}$ melaporkan 47 (47\%) pasien mendapatkan vitamin D, 26 di antaranya dengan PGK derajat 4-5. Hal ini dapat disebabkan karena vitamin $\mathrm{D}$ belum termasuk dalam tatalaksana rutin PGK stadium awal, hanya direkomendasikan untuk diberikan terutama pada PGK derajat 4-5.

Duapuluh tujuh pasien $(38,6 \%)$ menggunakan steroid. Proporsi pasien yang mendapat steroid lebih besar daripada laporan Stein, ${ }^{8}$ hanya $17,1 \%$ pasien mendapat steroid. Sementara Kalkwarf ${ }^{2}$ melaporkan $11,5 \%$ pasien mendapat steroid. Perbedaan ini dapat disebabkan karena SN merupakan etiologi terbanyak pada penelitian ini dibandingkan penelitian lainnya.

Terdapat 19 pasien yang mengalami hipoalbuminemia $(27,1 \%)$. Hipoalbuminemia dapat terjadi pada sekitar 49-68\% pasien dengan PGK, semakin rendah LFG maka akan semakin rendah albumin. ${ }^{12}$ Jumlah pasien hipoalbuminemia yang rendah mungkin disebabkan oleh pengambilan sampel darah albumin dilakukan juga pada pasien SN yang sedang tidak dalam kondisi relaps atau karena jumlah pasien PGK derajat 1 yang lebih banyak maupun karena asupan protein baik yang tidak diteliti dalam studi ini.

Proteinuria terjadi pada $29(41,4 \%)$ pasien. Soares ${ }^{13}$ melaporkan kejadian proteinuria yang lebih tinggi, yaitu $72 \%$ pada pasien PGK derajat 4-5. Begitu pula dengan Kamath $\mathrm{dkk}^{14}$ yang melaporkan kejadian proteinuria pada pasien PGK derajat 2-4 sebesar 93,5\%. Perbedaan ini mungkin disebabkan karena pemeriksaan protein urin pada penelitian ini masih menggunakan pemeriksaan secara kualitatif sehingga tidak dapat menilai proteinuria ringan atau mikroalbuminuria.

Pada analisis bivariat didapatkan bahwa hipoalbuminemia berhubungan dengan defisiensi vitamin $D$, sedangkan faktor risiko lain tidak menunjukkan hubungan bermakna. Hasil analisis multivariat dengan regresi logistik menunjukkan pasien PGK dengan usia 1-13 tahun, lama diagnosis $\geq 2$ tahun dan hipoalbuminemia lebih berisiko untuk mengalami defisiensi 25(OH)D.

Anak usia $<14$ tahun lebih berisiko untuk mengalami defisiensi 25(OH)D. Hal tersebut mungkin disebabkan oleh subjek penelitian yang lebih banyak pada usia 7-13 tahun, ataupun karena pada usia tersebut lebih banyak anak yang datang dengan sindrom nefrotik yang mengalami hipoalbuminemia, sehingga kejadian defisiensi 25(OH)D lebih tinggi. Pada penelitian ini, hasil ini juga dapat dipengaruhi karena pada subjek yang berusia 1-13 tahun masih lebih banyak dengan etiologi CAKUT, dan sebagian di antaranya adalah PGK stadium berat ataupun telah menjalani CAPD, dan memiliki paparan sinar matahri yang pendek di dalam rumah.

Pasien PGK dengan hipoalbuminemia berisiko lebih besar untuk terjadi defisiensi maupun insufisiensi $25(\mathrm{OH}) \mathrm{D}$ dibandingkan pasien yang tidak mengalami hipoalbuminemia. Hal ini karena semakin banyak protein yang hilang dalam darah maka semakin banyak kehilangan vitamin D-binding protein yang mengikat 25(OH)D maupun 1,25(OH)D. Vitamin D telah diketahui dapat memperlambat progresivitas PGK, mengurangi komplikasi, angka kesakitan dan angka kematian pasien PGK. Salah satu cara untuk menjaga agar tidak terjadi defisiensi $25(\mathrm{OH}) \mathrm{D}$ pada pasien PGK adalah dengan mencegah terjadi hipoalbuminemia pada pasien dengan cara pemberian suplementasi vitamin D, suplementasi makanan mengandung vitamin $\mathrm{D}$ serta mencegah proteinuria pada pasien PGK. ${ }^{2}$

Semakin lama penyakit terjadi, tentu semakin bertambah tingkat kerusakan dan keparahan penyakit. Semakin turunnya fungsi ginjal akan menyebabkan beberapa hal, seperti proteinuria, baik ringan maupun berat yang kronik serta penurunan kadar $1-\alpha$ hidroksilase yang akan menurunkan sintesis $25(\mathrm{OH}) \mathrm{D}$ menjadi 1,25(OH)D. ${ }^{1,5}$ Pada pasien dengan penyakit yang cukup berat, semakin turunnya aktifitas luar rumah maupun konsumsi makanan sehat akan semakin memperberat defisiensi 25(OH)D.

Keterbatasan penelitian ini adalah jumlah sampel yang belum cukup banyak sehingga terdapat 
subkelompok dengan subjek yang sangat sedikit seperti pada variabel pemakaian sunscreen, steroid, dan derajat PGK 2-4. Penelitian ini juga tidak menganalisis tentang modalitas terapi pengganti ginjal dan PTH.

\section{Kesimpulan}

Angka kejadian defisiensi vitamin D pada anak PGK yaitu $64,3 \%$. Faktor risiko yang bermakna terhadap kejadian defisiensi dan insufisiensi vitamin $\mathrm{D}$ yaitu hipoalbuminemia, usia $<14$ tahun dan lama sakit $\geq 2$ tahun.

\section{Daftar pustaka}

1. Kumar J, McDermott K, Abraham AG, dkk. Prevalence and correlates of 25-hydroxyvitamin D deficiency in the chronic kidney disease in children cohort. Pediatr Nephrol 2015:31;121-9.

2. Kalkwarf HJ, Denburg MR, Strife F, dkk. Vitamin D deficiency is common in children and adolescents with chronic kidney disease. Kidney Int 2012;81:690-7.

3. Kim CS, Kim SW. Vitamin D and chronic kidney disease. Korean J Intern Med 2014;29:416-27.

4. Aytac MB, Deveci M, Bek K, Kayabey O, Ekinci Z. Effect of cholecalciferol on local stiffness and endothelial dysfunction in children with chronic kidney disease. Pediatr Nephrol 2015;31:267-77.
5. Lee JY, So TY, Thackray J. A review on vitamin D defficiency treatment in pediatric patients J Pediatr Pharmacol Ther 2013;18:277-91.

6. National Kidney Foundation. K/DOQI clinical practice guidelines for chronic kidney disease: evaluation, classification, and stratification. Am J Kidney Dis 2002;39:S1-266.

7. Harambat J, Van Stralen KJ, Kim JJ, Tizard EJ. Epidemiology of chronic kidney disease in children. Pediatr Nephrol 2012;23:363-73.

8. Stein D, Feldman HA. Vitamin D status in children with chronic kidney disease. Pediatr Nephrol 2012;27:1341-50.

9. Seeherunvong W, Abitbol CL, Chandar J, Zilleruelo G, Freundlich M. Vitamin D insufficiency and deficiency in children with early chronic kidney disease. J Pediatr 2009;154:906-91.

10. Ardissino G, Daccò V, Testa S, dkk; ItalKid Project. Epidemiology of chronic renal failure in children: data from the ItalKid project. Pediatrics 2003;111:e382-7.

11. Mong Hiep TT, Ismaili K, Collart F, dkk. Clinical characteristics and outcomes of children with stage 3-5 chronic kidney disease. Pediatr Nephrol 2010;25:935-40.

12. Nirav S, Swati A, Divyen K, Nency L, Atodadiya J, Arjun M. Evaluation of epidemiological and clinical profile of newly diagnosed cases of chronic kidney disease in a tertiary healthcare center: A prospective study. Intern J Contemp Med Res 2018;5:E7-12.

13. Soares CMB, Diniz JSS, Lima EM, dkk. Clinical outcome of children with chronic kidney disease in a pre-dialysis interdisciplinary program. Pediatr Nephrol 2008;23:203946.

14. Kamath N, Iyengar A, George N, Luyckx VA. Risk Factors and Rate of Progression of CKD in Children. Kidney Int Rep 2019;4:1472-7. 